\title{
Taxonomy of the Azotobacteraceae Determined by Using Immunoelectrophoresis
}

\author{
Y. T. TCHAN, ${ }^{1 *}$ Z. WYSZOMIRSKA-DREHER, ${ }^{1}$ P. B. NEW, ${ }^{1}$ AND J.-C. ZHOU ${ }^{2}$ \\ Department of Microbiology, University of Sydney, New South Wales, 2006, Australia, ${ }^{1}$ and Hua-chung \\ Agricultural College, Wuhan, People's Republic of China ${ }^{2}$
}

\begin{abstract}
The similarities of various strains of Azotobacter spp. and Azomonas spp. to reference strains of Azotobacter paspali, Azotobacter vinelandii, Azotobacter chroococcum, Azomonas agilis, Azomonas insignis, and Azomonas macrocytogenes were determined by rocket line immunoelectrophoresis. The strains of Azotobacter paspali and Azotobacter vinelandii used were immunologically more homogeneous than the strains of Azotobacter chroococcum studied, possibly due to the more diverse geographical origins of the Azotobacter chroococcum strains. Low values were obtained for the mean immunological distances $(1-$ proportion of immunoprecipitation bands shared between strains) between Azotobacter paspali and Azotobacter vinelandii strains, suggesting that these two species are immunologically closely related. Immunological distances from the Azotobacter chroococcum reference strain were similar for Azotobacter paspali and for other undisputed members of the genus Azotobacter, which makes it reasonable to retain Azotobacter paspali in this genus. When the three Azotobacter antisera were used, all Azotobacter species had mean immunological distances of less than 0.5, whereas the Azomonas species were immunologically more distant, showing that the six species of Azotobacter form an immunologically related group which is distinct from the Azomonas species. Our results with the three Azomonas antisera show that each species of Azomonas is immunologically distant from the other species, as well as from the Azotobacter species. We compare our immunoelectrophoretic results with the molecular biological results of De Smedt et al. (Int. J. Syst. Bacteriol. 30:106-122, 1980) and the numerical taxonomic analysis of Thompson and Skerman (Azotobacteraceae: the Taxonomy and Ecology of the Aerobic Nitrogen-Fixing Bacteria, Academic Press, Inc., London, 1979).
\end{abstract}

Controversy concerning the taxonomy of the Azotobacteraceae has recently arisen after the publication of results of two different types of investigation. On the basis of a numerical taxonomy study, Thompson and Skerman $(11,12)$ proposed two new genera, Azorhizophilus Thompson and Skerman 1981 to accommodate Azotobacter paspali Döbereiner 1966 (5) and Azomonotrichon Thompson and Skerman 1981 to accommodate the organism previously known as Azomonas macrocytogenes (H. Jensen 1953) Baillie, Hodgkiss, and Norris 1962 (1).

This proposal is not supported by the results of De Smedt et al. (3), who found that Azotobacter paspali is indistinguishable from other Azotobacter species on the basis of ribosomal ribonucleic acid (rRNA) hybridization and the guanineplus-cytosine contents of their deoxyribonucleic acids (DNAs). Using the same criteria, De Smedt et al. (3) found that Azomonas agilis, Azomonas insignis, and Azomonas macrocytogenes are as distant from each other as they are from members of the genus Azotobacter. These authors stated that new genera should be established to accommodate each of the three species of Azomonas or, alternatively, all three species should be retained in the genus Azomonas until further research clarifies the situation.

Rocket line immunoelectrophoresis has previously revealed the presence of certain familyspecific and species-specific antigens in members of the Azotobacteraceae (10). In this paper we present data on the immunological affinities among various species in the family Azotobacteraceae and compare our results with those of Thompson and Skerman (11) and De Smedt et al. (3).

\section{MATERIALS AND METHODS}

Bacterial strains and growth conditions. The bacterial strains used in this study are listed in Table 1 . All cultures were grown at $30^{\circ} \mathrm{C}$ on Winogradsky nitrogenfree agar medium (10) and washed off the agar surface for preparation of antisera or antigens for immunoelectrophoresis.

Preparation of antisera. The method of Tchan et al. 


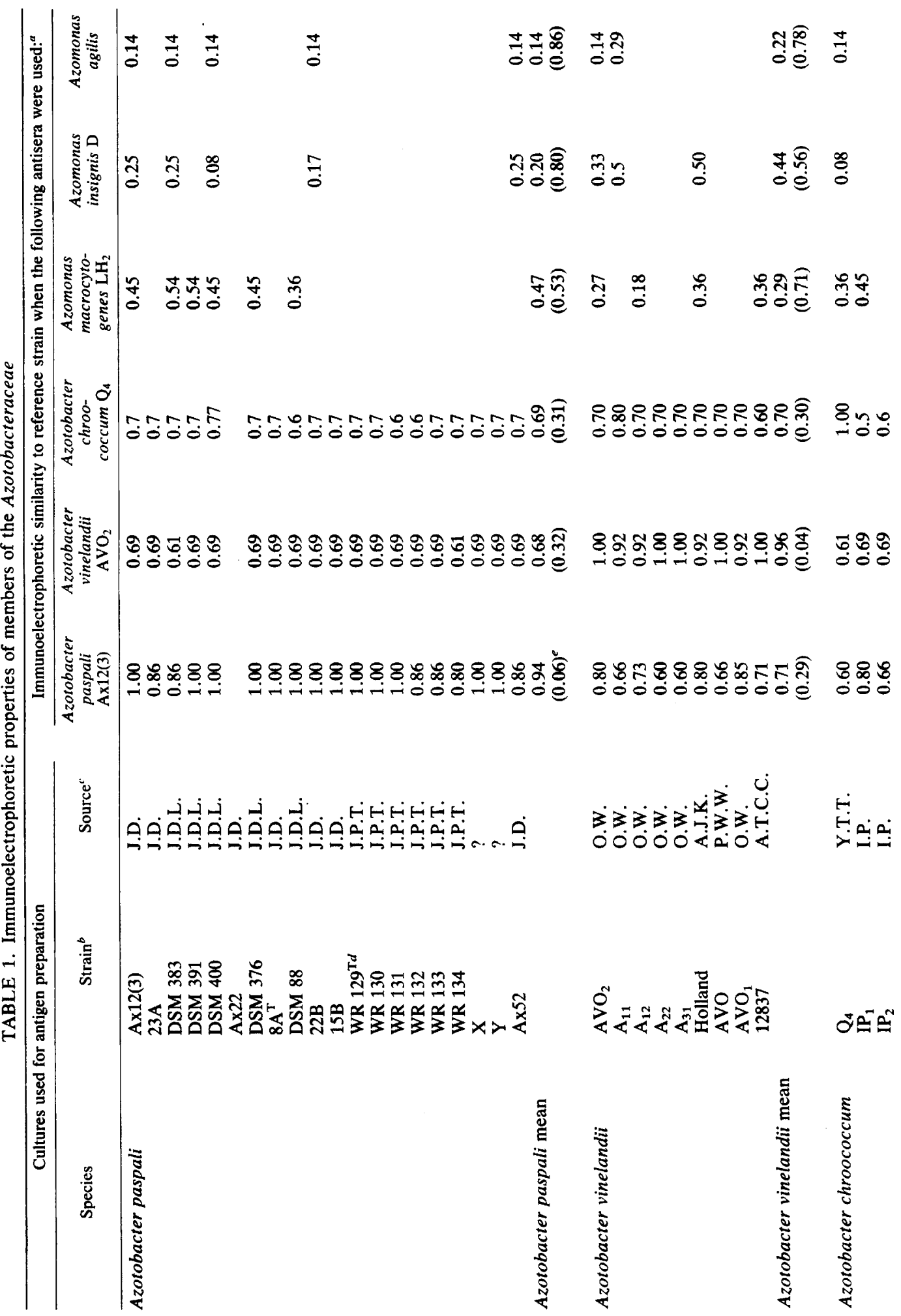




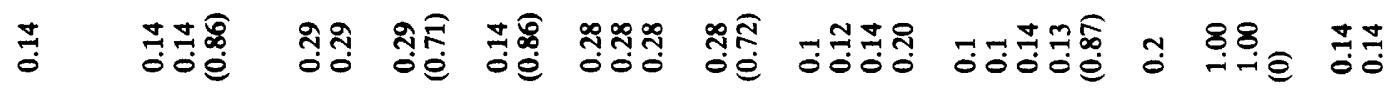

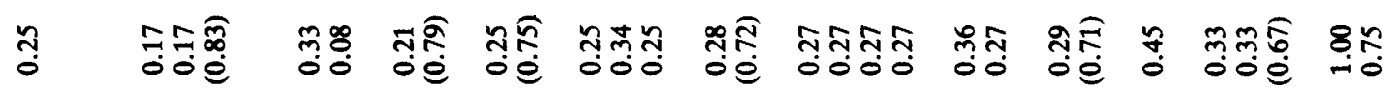

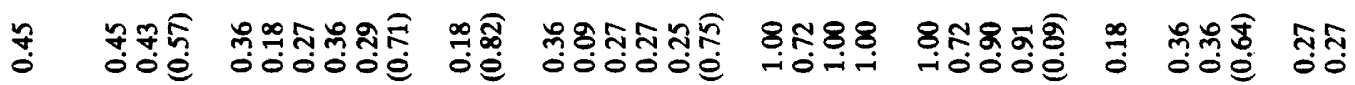

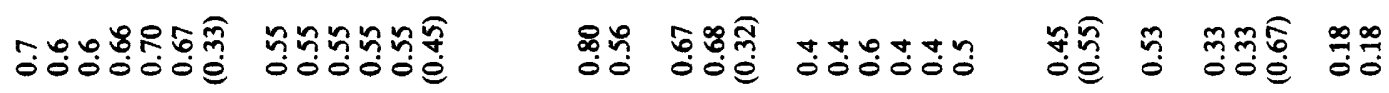

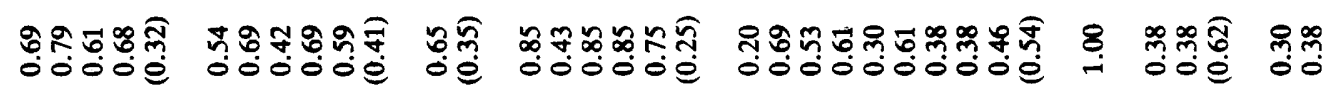

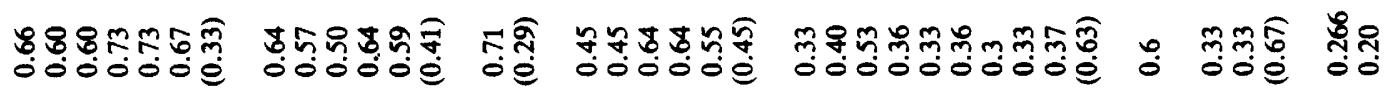

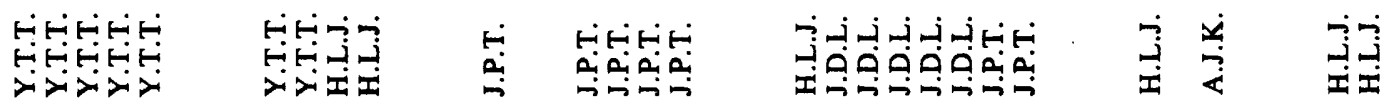

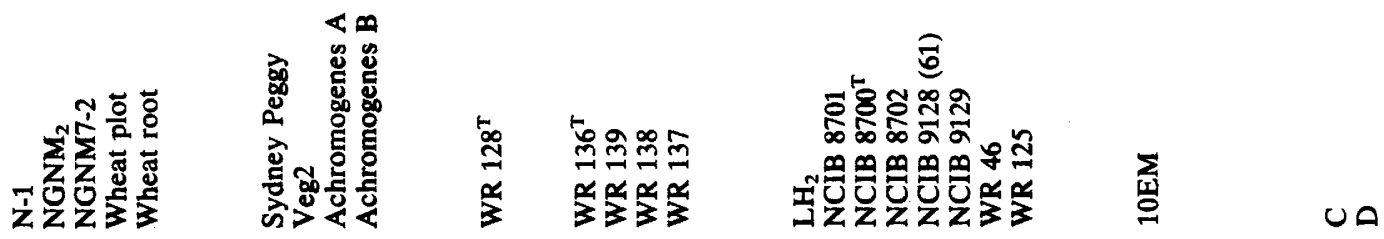

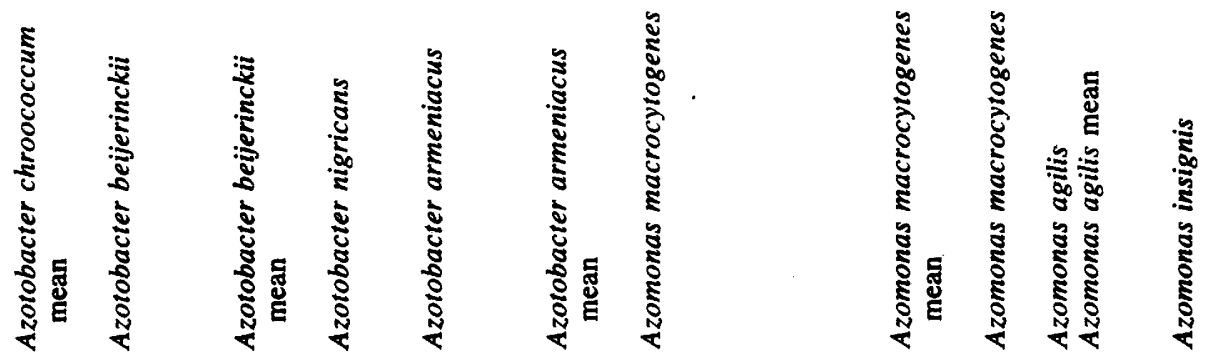




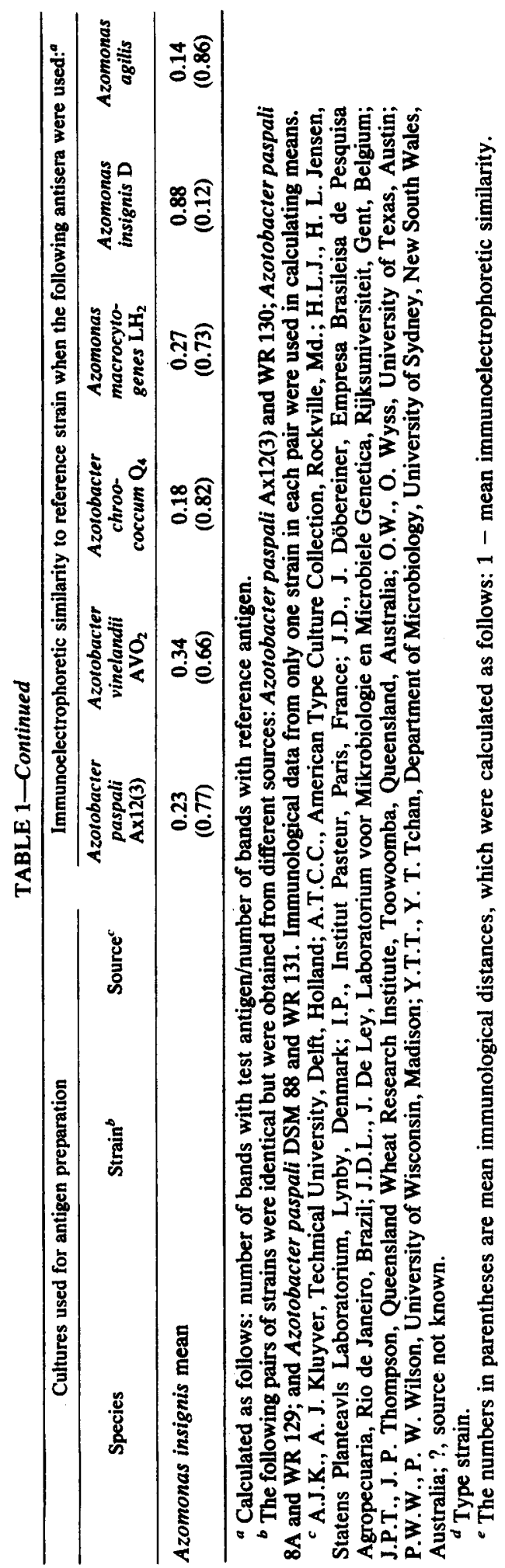

(10) was used to produce antisera in rabbits against whole cells of the following reference strains, which were suspended in $0.85 \% \mathrm{NaCl}$ : Azotobacter vinelandii $\mathrm{AVO}_{2}$, Azotobacter paspali Ax12(3), Azotobacter chroococcum $\mathrm{Q}_{4}$, Azomonas macrocytogenes $\mathrm{LH}_{2}$, Azomonas agilis, and Azomonas insignis D.

Preparation of antigens for immunoelectrophoresis. Bacterial cells suspended in distilled water were broken by ultrasonic disintegration for 3 to $10 \mathrm{~min}$ with a Biosonik II sonicator (Bronwill Scientific Inc., Rochester, N.Y.) with the power output control set at 90. An ice bath was used to maintain a low temperature during sonication, and cell breakage was checked regularly by phase-contrast microscopy until 80 to $90 \%$ cell breakage was achieved.

Each antigen was freeze-dried and suspended in saline to a concentration of $\mathbf{4 0} \mathrm{mg}$ (dry weight) per $\mathrm{ml}$.

Immunoelectrophoresis. Immunological similarities to the reference strains were determined after rocket line immunoelectrophoresis by the method of Kroll (7), in which antigens of the various strains were placed in wells. The antigens prepared from the reference strain were incorporated in the reference strip, as well as in one of the wells. All wells contained $10 \mu \mathrm{l}$ of antigen preparation. The following concentrations were used for the reference antigen strips (milligrams [dry weight] of antigen per cubic centimeter of gel): Azotobacter paspali, 5.2; Azotobacter vinelandii, 1.2; Azotobacter chroococcum, 4; Azomonas macrocytogenes, 3.5; Azomonas agilis, 8; Azomonas insignis, 8. The antigens were electrophoresed into a gel containing antiserum prepared against the reference strain. The following concentrations of antisera were used (microliters of antiserum per square centimeter of gel): Azotobacter paspali, 6; Azotobacter vinelandii, 8; Azotobacter chroococcum, 12; Azomonas macrocytogenes, 7; Azomonas agilis, 18; Azomonas insignis, 12.

Agarose A (Pharmacia Fine Chemicals A.B., Uppsala, Sweden) was used to prepare all gels except the reference antigen strip, which was prepared from lowtemperature-gelling agarose B (Pharmacia) to avoid heating the antigens above $40^{\circ} \mathrm{C}$.

Electrophoresis was carried out with a total output of $80 \mathrm{~V}$ (corresponding to $1 \mathrm{~V} / \mathrm{cm}$ ) for $16 \mathrm{~h}$. Coomassie brilliant blue $\mathbf{R}$ was used for plate staining.

Immunoelectrophoretic similarity was calculated from the proportion of antigen-antibody precipitation bands shared by a reference strain and another strain, when they were electrophoresed against antiserum prepared against the reference strain (Fig. 1 and 2). This result was used to calculate the immunological distance from the reference strain (immunological distance is defined as follows: 1 - proportion of shared bands). For example, in calculating the immunological relatedness between reference strain Azotobacter paspali $\mathrm{Ax} 12(3)$ and Azomonas macrocytogenes $\mathrm{LH}_{2}$, the following data were obtained: the homologous antigen produced 15 bands, and strain $\mathrm{LH}_{2}$ produced 5 bands. Thus, the immunoelectrophoretic similarity is $5 / 15=$ 0.33 , and the immunological distance is $1-0.33=$ 0.67 .

Since formation of precipitation bands or peaks is a function of the ratio of antigen molecules to antibody molecules, the absence of a particular band does not necessarily imply complete absence of the antigen, but rather shows that the concentration of this antigen in the strain being tested is significantly lower than the 


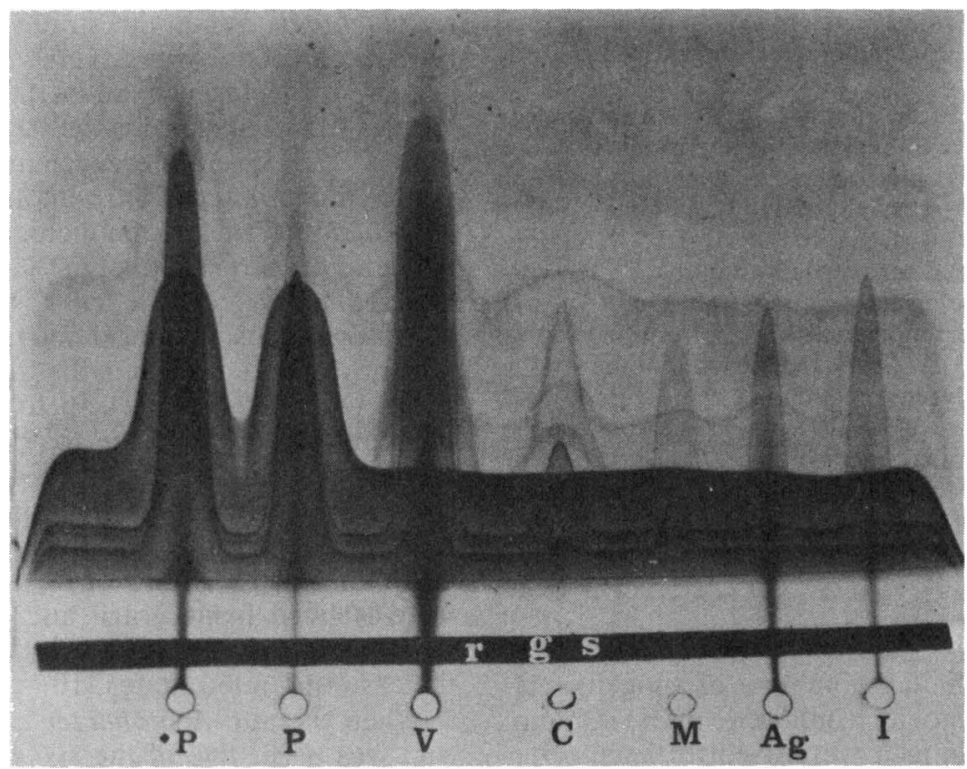

FIG. 1. Rocket line immunoelectrophoresis of members of the Azotobacteraceae. The gel contained antiAzotobacter paspali Ax12(3) serum. r g s, Reference gel strip containing Azotobacter paspali Ax12(3) antigen. The following antigens were in the wells: $\rightarrow$ P, Azotobacter paspali Ax12(3); P, Azotobacter paspali DSM 383; V, Azotobacter vinelandii $\mathrm{AVO}_{2} ; \mathrm{C}$, Azotobacter chroococcum $\mathrm{Q}_{4} ; \mathrm{M}$, Azomonas macrocytogenes $\mathrm{LH}_{2} ; \mathrm{Ag}$, Azomonas agilis; I, Azomonas insignis D. Even though all precipitation lines are not visible in the photograph, it is evident that more horizontal precipitation lines are elevated to form peaks above the wells containing Azotobacter antigens than above the wells containing Azomonas antigens. The close immunological relationship between Azotobacter paspali and Azotobacter vinelandii is apparent.

concentration in the reference strain against which the antiserum was produced. We believe that a concentration difference large enough to cause the nonappearance of a band should be counted as an absolute difference for the purpose of taxonomic comparison under our standardized conditions. It should be appreciated that two strains having similar immunological distances from a common reference strain may not necessarily be closely related, since they may have different antigens in common with the reference strain. For example, two strains with immunological distances of more than $\mathbf{0 . 5}$ from the same reference strain theoretically may have no common bands when they are tested against the reference antiserum. For two strains with immunological distances of less than 0.5 , the maximum possible distance apart (based on anti-

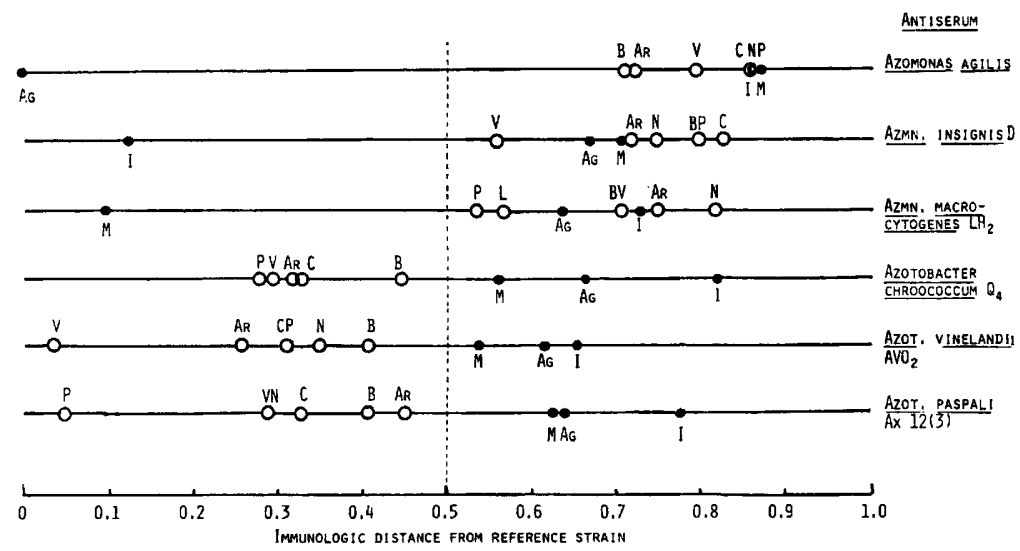

FIG. 2. Mean immunological distance of species of Azotobacter (O) and Azomonas (O) from reference strains. AG, Azomonas agilis; I, Azomonas insignis; M, Azomonas macrocytogenes; AR, Azotobacter armeniacus; B, Azotobacter beijerinckii; C, Azotobacter chroococcum; N, Azotobacter nigricans; P, Azotobacter paspali; V, Azotobacter vinelandii. 
gens in common with the reference strain) is the sum of their respective immunological distances from the reference strain.

Comparison between immunological data and molecular biological results. To investigate groupings by the different methods, plots of mean denaturation temperature of DNA-rRNA hybrids $\left[T_{m(e)}\right]$ versus mean percent binding of rRNA to DNA (rRNA binding percentage) were superimposed on plots of $T_{m(e)}$ versus mean immunological distance. Values of $T_{m(e)}$ and rRNA binding percentage were taken from the data of De Smedt et al. (3) by averaging the data for the strains tested in our study; if no common strains were tested, the mean for the species was based upon all of the strains tested by De Smedt et al. (3). The scales for rRNA binding percentage and mean immunological distance were chosen so that the data points would span approximately the same horizontal range.

\section{RESULTS}

Because of the large number of antigens tested, many immunoelectrophoretic plates containing reference antigen were used for each reference antiserum. The number of precipitation peaks formed by the reference antigen against its homologous antiserum was highly reproducible, with a maximum difference of one precipitation peak between plates (Table 2).

Our data indicate that all members of the Azotobacteraceae have some taxonomic relationship, since they all share some antigens with the reference strains, whereas other nitrogenfixing bacteria (Beijerinckia and Rhizobium) show no cross-reaction (10). The mean immunological distances of the various species from the reference strains are shown in Table 1 and Fig. 2.

It is apparent that members of Azotobacter paspali and Azotobacter vinelandii are immunologically homogeneous within species, as the immunological distances from the corresponding reference strains ranged from 0 to 0.2 for Azotobacter paspali and from 0 to 0.08 for Azotobac- ter vinelandii. When the strains of Azotobacter paspali and Azotobacter vinelandii were tested against the reference antiserum of the other species (Azotobacter paspali strains versus Azotobacter vinelandii reference antiserum and vice versa), Azotobacter paspali and Azotobacter vinelandii had mean immunological distances of 0.31 and 0.32 , respectively.

Azotobacter chroococcum strains may be considerably less homogeneous, as their immunological distances from the reference strain, strain $Q_{4}$, ranged from 0.50 to 0.30 . Although this could have been due to the choice of the reference strain, the greater diversity of the Azotobacter chroococcum strains probably also reflects the geographical diversity of their origins, whereas all strains of Azotobacter paspali were isolated from Brazil and the majority of Azotobacter vinelandii strains originated from the eastern United States (10).

When the anti-Azotobacter chroococcum serum was used, five of the six Azotobacter species tested had the same degree of immunological similarity to the reference strain, based on mean immunological distance. Although the mean immunological distance of Azotobacter beijerinckii was greater, the individual distances of all of its strains from the reference strain lay within the range of variation of Azotobacter chroococcum strains (Table 1). Among the Azotobacter species, Azotobacter beijerinckii had the lowest similarity to the Azotobacter reference strains, except in the tests against Azotobacter paspali antiserum, where the value for Azotobacter armeniacus was lower (Table 1).

The immunological distances of some Azomonas macrocytogenes strains from the reference Azotobacter strains were less than the immunological distances of some strains of the least similar Azotobacter species, especially when Azotobacter vinelandii was used. Azomonas macrocytogenes strain $10 \mathrm{EM}$ was immu-

TABLE 2. Number of precipitation peaks produced by reference antigen against homologous antiserum or immunoelectrophoretic plates

\begin{tabular}{|c|c|c|}
\hline Reference antiserum & $\begin{array}{l}\text { No. of peaks } \\
\text { with reference } \\
\text { antigen }\end{array}$ & Species tested \\
\hline Azotobacter paspali Ax12(3) & 15 & $\begin{array}{l}\text { Azotobacter paspali, Azotobacter vinelandii, Azotobac- } \\
\text { ter chroococcum, Azomonas macrocytogenes, Azo- } \\
\text { monas agilis, Azomonas insignis }\end{array}$ \\
\hline Azotobacter paspali Ax12(3) & 14 & Azotobacter armeniacus, Azotobacter beijerinckii \\
\hline Azotobacter vinelandii $\mathrm{AVO}_{2}$ & 26 & All species \\
\hline Azotobacter chroococcum $\mathrm{Q}_{4}$ & 10 & $\begin{array}{l}\text { Azotobacter chroococcum, Azotobacter vinelandii, Azo- } \\
\text { monas macrocytogenes }\end{array}$ \\
\hline Azotobacter chroococcum $\mathrm{Q}_{4}$ & 9 & $\begin{array}{l}\text { Azotobacter armeniacus, Azotobacter beijerinckii, Azo- } \\
\text { monas agilis, Azomonas insignis }\end{array}$ \\
\hline Azomonas macrocytogenes $\mathrm{LH}_{2}$ & 11 & All species \\
\hline Azomonas agilis & 7 & All species \\
\hline Azomonas insignis $\mathrm{D}$ & 12 & All species \\
\hline
\end{tabular}




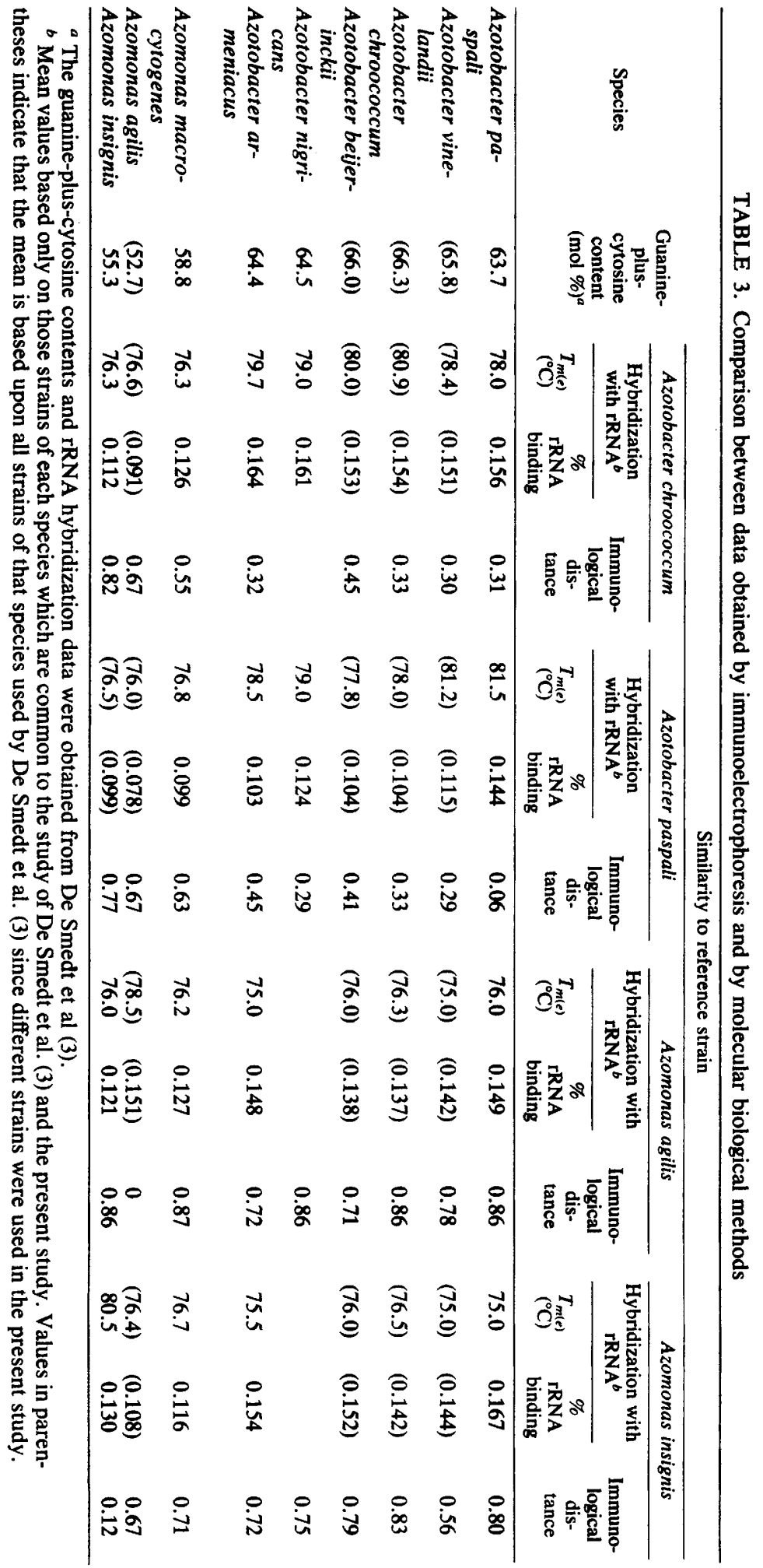



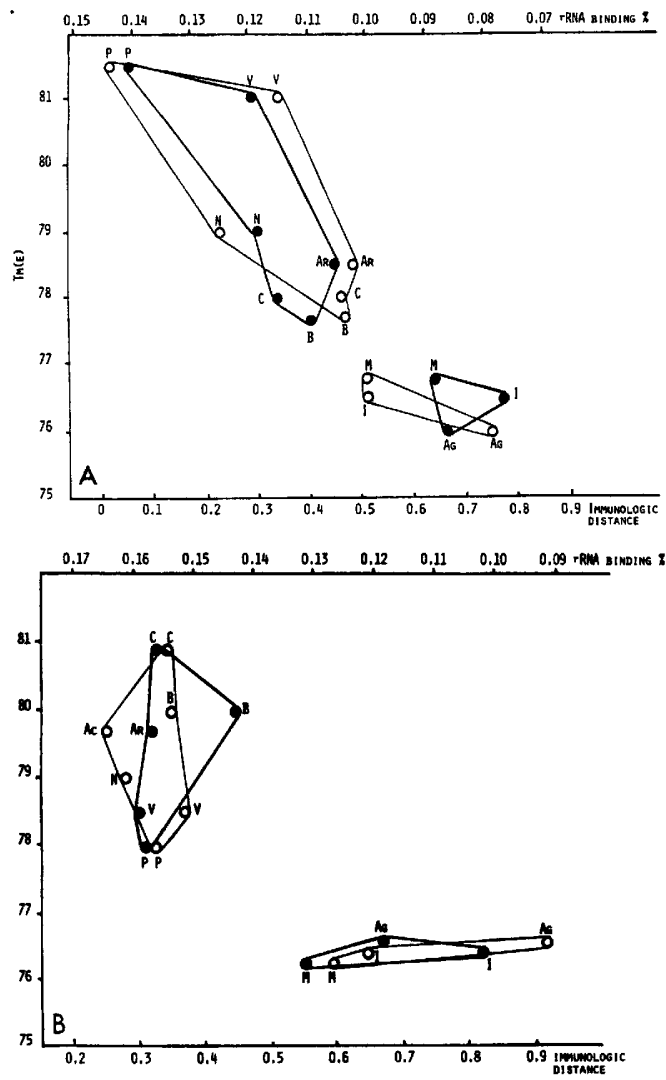

FIG. 3. Maps of similarity of species of Azotobacter and Azomonas to Azotobacter paspali (A) and Azotobacter chroococcum (B). $T_{m(e)}$ of DNA-rRNA hybrids is plotted against mean percent binding of rRNA to DNA (rRNA binding percentage) $(O)$ and against mean immunological distance from the reference strain (O). $T_{m(e)}$ and rRNA binding percentages were taken from the data of De Smedt et al. (3). (A) The reference strains used were Azotobacter paspali $8 \mathrm{~A}$ (for $T_{m(e)}$ and rRNA binding percentage) and Ax12(3) (for immunological distance). (B) The reference strains used were Azotobacter chroococcum NCIB 8002 (for $T_{m(e)}$ and rRNA binding percentage) and $\mathrm{Q}_{4}$ (for immunological distance). AG, Azomonas agilis; I, Azomonas insignis; M, Azomonas macrocytogenes; AR, Azotobacter armeniacus; B, Azotobacter beijerinckii; C, Azotobacter chroococcum; N, Azotobacter nigricans; P, Azotobacter paspali; V, Azotobacter vinelandii.

nologically distant from the reference Azomonas macrocytogenes strain, but very similar to Azotobacter vinelandii, as previously noted by Tchan et al. (10). When tested against antiAzotobacter paspali serum, strain 10EM gave a similar result to the Azotobacter vinelandii $\mathrm{AVO}_{2}$ antigens. For this reason, strain 10EM was excluded from our calculation of mean immunological distance for Azomonas macrocy. togenes to avoid distorting the value toward
Azotobacter vinelandii. However, it was not considered desirable to include strain 10EM in the calculations for Azotobacter vinelandii in the absence of supporting phenotypic or molecular biological data.

When the three Azotobacter antisera were used, the mean immunological distance of the three Azomonas species was always greater than the value for any Azotobacter species, supporting the separation of this genus from Azotobacter. The results obtained with anti-Azomonas agilis, anti-Azomonas insignis, and anti-Azomonas macrocytogenes reference sera confirmed the separation of the three Azomonas species from all species of Azotobacter, but also clearly showed that the Azomonas species are immunologically distant from one another ( $\mathrm{Ta}$ ble 1 and Fig. 2).

\section{DISCUSSION}

Vincent $(13,14)$ has previously pointed out that groupings of the rhizobia obtained by serology agree well with groupings obtained by molecular biological methods. However, the immunodiffusion technique used by this author was able to resolve only a limited number of precipitation bands, which were inadequate for mathematical analysis. The immunoelectrophoretic technique, with its higher resolving power, is better suited to make comparisons between immunological results and molecular biological data. For this reason, we compared our immunological results for the Azotobacteraceae with the molecular biological results of De Smedt et al. (3) (Table 3), who studied the similarities between rRNA cistrons of several reference strains and a variety of strains of Azotobacter and Azomonas. rRNA is regarded as a conservative molecule $(6,8,9)$, and the degree of rRNA similarity correlates well with overall phenotypic similarity between groups of bacteria which are too different from one another to be compared by DNA-DNA hybridization (2-4).

When Azotobacter paspali reference strains are used, there is good agreement between superimposed maps (Fig. 3A), indicating good correspondence between immunological distance and rRNA binding percentage; in fact, the correlation coefficients $(r)$ between these parameters are highly significant $(P<0.01)$ for the Azotobacter species $(r=-0.94)$ and for the Azotobacter plus Azomonas species ( $r=$ $-0.86)$. The correlation between $T_{m(e)}$ and immunological distance is also significant for the Azotobacter plus Azomonas species $(r=-0.89$, $P<0.01$ ), but not for the Azotobacter species alone. The superimposed maps do not agree as well for the Azomonas species, and the immunological data provide a greater separation between the Azomonas and Azotobacter groupings. 
There is less similarity between the superimposed maps when Azotobacter chroococcum reference strains are used (Fig. 3B); however, the separation between the Azotobacter and Azomonas groups is similar. Correlations between rRNA binding percentage or $T_{m(e)}$ and immunological distance are not significant for Azotobacter species alone, although there are significant correlations with immunological distance for the Azotobacter plus Azomonas species $[r=-0.88, P<0.01$ for rRNA; $r=-0.73$, $P<0.05$ for $\left.T_{m(e)}\right]$.

Data were not plotted for Azomonas agilis or Azomonas insignis reference strains, since the means were based on fewer points and therefore were less reliable. For both species, $T_{m(e)}$ but not rRNA binding percentage is significantly correlated with immunological distance, based on Azomonas plus Azotobacter species (for Azomonas agilis, $r=-0.79, P<0.05$; for Azomonas insignis, $r=-0.80, P<0.05) . T_{m(e)}$ gives the same general result as immunological distance, with the reference Azomonas species on its own (i.e., separated from all other Azomonas and Azotobacter species) (Fig. 2).

Thus, the results obtained by our immunoelectrophoretic investigation are in agreement with those obtained by molecular biological methods (3) despite the possible shortcoming of comparing our phenotypic results with the data of De Smedt et al. It is possible that differences in order of similarity between these sets of results may be due to the use of different reference strains in the case of Azotobacter chroococcum, Azomonas agilis, and Azomonas insignis, since very good agreement between the two methods was obtained for Azotobacter paspali, for which two immunologically identical reference strains were used; strain $8 \mathrm{~A}$, which was used by De Smedt et al. (3), is immunologically indistinguishable from strain Ax12(3).

Our results indicate that Azotobacter paspali is immunologically similar to Azotobacter vinelandii (immunological distances of $\mathbf{0 . 3 1}$ for $\mathrm{Azo}$ tobacter vinelandii against Azotobacter paspali antiserum and 0.32 for Azotobacter paspali against Azotobacter vinelandii antiserum). When strains were tested against anti-Azotobacter chroococcum serum, the mean immunological distance and range of distances of Azotobacter paspali from the reference strain were similar to those of other undisputed members of the genus, including Azotobacter chroococcum, which is the type species of Azotobacter. Therefore, it seems reasonable to include Azotobacter paspali in the genus Azotobacter, a conclusion which is in agreement with the molecular biological evidence (3), but not in accord with the classification obtained by numerical taxonomy (11).
Azomonas macrocytogenes was not immunologically close to Azotobacter paspali (11) or to any other species of Azotobacter, although it is more closely related to Azotobacter than the other Azomonas species are. The DNA base composition of this species is also intermediate between the base compositions of the azotobacters and the other members of the genus Azomonas (guanine-plus-cytosine contents: Azotobacter species, 63.2 to $67.5 \mathrm{~mol} \%$; Azomonas macrocytogenes, 58.2 to $58.6 \mathrm{~mol} \%$; Azomonas insignis, 55.1 to $58.3 \mathrm{mol \%}$; and Azomonas agilis, 52.0 to $53.2 \mathrm{~mol} \%$ ). Our results, together with the molecular biological data of De Smedt et al. (3), lend support to the establishment by Thompson and Skerman (11) of a separate genus for Azomonas macrocytogenes.

Although Azomonas agilis and Azomonas insignis are both immunologically distant from the reference strains of the Azotobacter species, it is not possible to conclude from this that these two Azomonas species are closely related. The results obtained with antisera against Azomonas agilis and Azomonas insignis show that these species are immunologically distinct and could even be placed in two distinct genera. Therefore, we have reservations concerning the retention of Azomonas agilis and Azomonas insignis in the same genus, as proposed by Thompson and Skerman (11). However, more strains of these species must be tested before a final conclusion can be reached. The establishment of a new genus to accommodate Azomonas insignis (3) should be given serious consideration if the present results are confirmed.

\section{ACKNOWLEDGMENTS}

We thank J. De Ley, Johanna Döbereiner, and J. P. Thompson for supplying some of the cultures used in this work. Our thanks are also extended to Margaret Hailwood for typing the manuscript.

The financial support received from a University of Sydney research grant is acknowledged.

\section{LITERATURE CITED}

1. Baillie, A., W. Hodgkiss, and J. R. Norris. 1962. Flagellation of Azotobacter spp. as demonstrated by electron microscopy. J. Appl. Bacteriol. 25:116-119.

2. De Ley, J., P. Segers, and M. Gillis. 1978. Intra- and intergeneric similarities of Chromobacterium and Janthinobacterium ribosomal ribonucleic acid cistrons. Int. J. Syst. Bacteriol. 28:154-168.

3. De Smedt, J., M. Bauwens, R. Tytgat, and J. De Ley. 1980. Intra- and intergeneric similarities of ribosomal ribonucleic acid cistrons of free-living, nitrogen-fixing bacteria. Int. J. Syst. Bacteriol. 30:106-122.

4. De Smedt, J., and J. De Ley. 1977. Intra- and intergeneric similarities of Agrobacterium ribosomal ribonucleic acid cistrons. Int. J. Syst. Bacteriol. 27:222-240.

5. Döbereiner, J. 1966. Azotobacter paspali sp.n., uma bacteria fixadora de nitrogenia na rizosfera de Paspalum. Pesqui. Agropecu. Bras. 1:357-365.

6. Dubnau, D., I. Smith, P. Morrell, and J. Marmur. 1965. Gene conservation in Bacillus species. I. Conserved generic and nucleic acid base sequence homologies. Proc. 
Natl. Acad. Sci. U.S.A. 54:491-498.

7. Kroll, J. 1973. Rocket-line immunoelectrophoresis, p. 8387. In N. H. Axelsen, J. Krøll, and B. Weeke (ed.), A manual of quantitative immunoelectrophoresis. Scand. J. Immunol. Suppl. 1, Universitetsforlaget, Oslo.

8. Moore, R. L., and B. J. McCarthy. 1967. Comparative study of ribosomal ribonucleic acid cistrons in enterobacteria and myxobacteria. J. Bacteriol. 94:1066-1074.

9. Takahashi, H., H. Salto, and Y. Ikeda. 1967. Species specificity of the ribosomal RNA cistrons in bacteria. Biochim. Biophys. Acta 134:124-133.

10. Tchan, Y. T., Z. Wyszomirska-Dreher, and J. M. Vincent. 1980. Preliminary study of taxonomy of Azotobacter and Azomonas by using rocket line immunoelectrophoresis. Curr. Microbiol. 4:265-270.
11. Thompson, J. P., and V. B. D. Skerman. 1979. Azotobacteraceae: the taxonomy and ecology of the aerobic nitrogen-fixing bacteria. Academic Press, Inc., London.

12. Thompson, J. P., and V. B. D. Skerman. 1981. Validation of the publication of new names and new combinations previously effectively published outside the IJSB. List no. 6. Int. J. Syst. Bacteriol. 31:215-218.

13. Vincent, J. M. 1974. Root-nodule symbioses with Rhizobium, p. 265-341. In A. Quispel (ed.), The biology of nitrogen fixation. North-Holland Publishing Co., Amsterdam.

14. Vincent, J. M. 1977. Rhizobium: general microbiology, p. 277-366. In R. W. F. Hardy and W. S. Silver (ed.), A treatise on dinitrogen fixation, sect. III. Biology. John Wiley \& Sons, Inc., New York. 